\title{
A BALATON RÉGIÓ NÉPESSÉGDINAMIKÁJA 2017-2062 KÖZÖTT
}

\author{
OBÁDOVICS CSILLA \\ POPULATION DYNAMICS IN THE BALATON REGION \\ BETWEEN 2017 AND 2062
}

\begin{abstract}
The present study examines the population projection of the settlements of the Balaton Region (BKÜ) by 2062, taking into account 180 settlements. The results are presented for the main age groups of the region, at five-year intervals, and broken down as follows: 18 cities, coastal villages (group of 39 settlements), and non-coastal villages (group of 123 settlements). The most recent research report on which this study is based was produced in 2017. For the two years since then, we can also identify deviations from previously forecasted processes. Using another method, we interrogate the reliability of the previous prediction. The population projection shows that the population of the resort area will fall to 184,000 by 2062 , and the proportion of the population over the age of 65 will reach or even exceed $35 \%$. In addition to the aging of the villages, the depopulation of dwarf villages further away from the coast poses a serious problem.
\end{abstract}

Keywords: Population projection, ageing, Balaton Region, depopulation

\section{Bevezetés}

A Balaton Régió demográfiai szempontú vizsgálata már húsz évvel ezelőtt is érdeklődésre tartott számot. Speciális térségről van szó, amelynek népesedési folyamatait sok egyéb tényező is befolyásolja, kezdve a területi elhelyezkedésétől - a Balaton közelsége, vagy a gazdaságban a turisztika túlsúlya (KSH 2011). Hablicsek László 2003-ban készült népesség előreszámítása a Balaton Régió városaira és parti-nem parti községcsoportokra előrevetítette a népesség számának, nemek és korcsoportok szerinti összetételét és változását. A népesség-előreszámítás nem egyszerú feladat, hiszen nincs arra garancia, hogy a korábbi tendenciák a jövőben hasonlóképpen folytatódnak. Ezért nagyon körültekintően kell eljárni, amikor a jövőre nézve demográfiai folyamatok, népmozgalmi tendenciák „jóslására” teszünk kísérletet. A népesség-előreszámítás nem egyszerú továbbvezetése a korábbi tendenciáknak, hanem a jövőre vonatkozóan a termékenységre, a születéskor várható élettartamra és a vándorlási folyamatokra különböző feltételezéseket állítunk fel, amelyek kombinációi többféle forgatókönyvet alkotnak. Ezek mentén számoljuk ki a jövőre vonatkozó népességszámokat. A bizonytalan jövőbeli folyamatok népesség-előreszámításba történő beépítésekor igen óvatosnak kell lenni.

A Balaton Régió 2003-ban készült népesség-előreszámítása során a fó irányvonalat az adta, hogy a népességszám növekedés hosszabb távon fennmaradjon. Ezért a tanulmány háromféle változatában a hipotézisek a vándorlás alakulására vonatkoztak. A vándorlás alapváltozata szerint az 1996-2000 között mért pozitív irányú vándorlási tendencia hoszszabb távú folytatódását feltételezték. Az összes tényező figyelembevételével az adott négy év migrációs folyamatainak folytatódása a népességszám emelkedését biztosította volna. A 2016-os továbbvezetett adatok Hablicsek számításához képet 6\%-kal alacsonyabb népességszámot mutatnak, azaz 15 ezer fóvel kevesebben éltek a Régióban, mint ahogyan az előrejelzés szerint várható volt (OBÁDOviCs 2017a). Az 1,2\%-os népességnövekedés helyett 
2,3\%-os népességcsökkenés következett be. A népességnövekedést a negatív szaporodási különbözetet felülmúló pozitív vándorlási egyenlegre alapozták, amely néhány várostól eltekintve messze elmaradt a kívánt értéktől.

A Régióra a népesség stabilitását, enyhe emelkedését becsülték a kutatók, azonban ez nem teljesült: az össznépesség kismértékű csökkenése következett be, továbbá a belső egyenlőtlenségek mérséklődése helyett nőttek a különbségek. A korszerkezetre vonatkozó főbb tendenciák természetesen helytállóak voltak, azaz a népesség öregszik, a fiatalok aránya csökken. A belső egyenlőtlenségek terén tapasztalható néhol szignifikáns eltérés, ami vagy a korábbi extrém, rendhagyó folyamatok következménye, vagy a nem várt további népmozgalmi mutatók alakulásának tulajdonítható (OBÁDOVICS 2017a).

Jelen tanulmány a Balaton Fejlesztési Tanács forrásainak felhasználásával és a Balatoni Integrációs és Fejlesztési Ügynökség Közhasznú Nonprofit Kft. megrendelésére a KSH Népességtudományi Kutatóintézetében készült 2016-os kutatás átdolgozásával, továbbfejlesztésével és kiegészítésével keletkezett. A tanulmány a Balaton Kiemelt Üdülőkörzet (BKÜ) településeinek 2062-ig tartó népesség-előreszámításáról szól 180 település figyelembevételével. Az eredményeket a Régió népességének fó korcsoportjaira, 5 éves intervallumokban, az alábbi területi bontásban adjuk meg: 18 város együttese, partközeli községek (39 község együttese), nem parti községek (123 község együttese, háttértelepülések). Az utolsó - e tanulmány alapját képező - kutatási jelentés 2017-ben készült (OBÁdOvics 2017b). Az azóta eltelt 2-3 évre a korábban előrejelzett folyamatoktól való eltéréseket is azonosítani tudjuk. A korábbi előreszámítás megbízhatóságát más módon történő előreszámítás alkalmazásával ellenőrizzük.

\section{Adat és módszer}

A területi népesség-előreszámítás kohorsz-komponens módszerrel készült (A módszerről bővebben lásd HABLICSEK 2009, FöLdHÁZi 2012, AlHO and SPENCER 2005, SMITH et al 2002). Az előreszámítás során a 2001-, 2011-, 2014-, 2015- és 2016-os évek demográfiai alapadatait és népmozgalmi folyamatait vettük alapul. Az előreszámítás kiinduló éve a 2016-os év. A népességszám és népmozgalmi (születés, halálozás, belföldi és nemzetközi vándorlás) adatok forrása a KSH, az adatok településekre vonatkozóan koréves bontásban álltak rendelkezésre. Az eredményeket ötéves periódusokban, összesen 10 időpontra számoltuk ki. Az első év 2017, majd 2022 következik, az utolsó év 2062. A kohorsz-komponens módszer alkalmazása során a népesség nemenkénti és korcsoportonkénti vagy korévenkénti létszámait továbbvezetjük a különbözó népmozgalmi folyamatok beépítésével. Felhívjuk a figyelmet a kis területi becslés magas fokú bizonytalanságára, így az eredmények felhasználása során azokat nagyfokú körültekintéssel és óvatossággal kell kezelni.

A népesség-előreszámításhoz a jövőre vonatkozóan hipotéziseket állítottunk fel a következő mutatókra: fertilitási (termékenységi) ráta, születéskor várható élettartam nőkre és férfiakra, teljes (állandó és ideiglenes) vándorlási egyenleg.

Két különböző eljárást alkalmazva az eredmények megbízhatóságát is teszteltük. Az első eljárás az agglomeratív eljárás, amelynek során a településenkénti népesség-előreszámítási eredményeket összegeztük a különböző csoportok szerint, így keletkezett a parti községekre, a háttértelepülésekre és a városokra az összesített eredmény. Ezt a számítást saját készítésú Excel számolótábla segítségével végeztük.

A másik eljárás során eleve az összesített adatokkal dolgoztunk, a területi elhelyezkedés és népességdinamikai csoport (KULCSÁR L.-OBÁDOviCs Cs. 2016) egészére végeztük el az előreszámítást, csoportonként meghatározva a termékenységi és halálozási paramé- 
tereket. Területi elhelyezkedés szerint a parti és a nem parti településeket különböztettük meg, népességdinamika szerint pedig a népesedő és népességvesztő települések csoportját határoztuk meg, ezen belül is szétválasztva aszerint, hogy a települést a természetes szaporodás/fogyás, illetve bevándorlás vagy elvándorlás jellemzi. A különböző részcsoportokban eltérő fertilitást és születéskor várható élettartam értékeket adtunk meg az előreszámítási folyamatban. Ehhez a számításhoz a Spectrum 5 szoftvert alkalmaztuk.

\section{Alapozó számítások}

Az előreszámítás alapját a 2001-2016 közötti demográfiai folyamatok képezték. A népesség-előreszámítást megalapozandó először a lakónépesség számának változását és a változást eredményező összetevőket, népmozgalmi idősoros adatokat tekintjük át.

\section{A Balaton Kiemelt Üdülökörzet áttekintése \\ - népesség és népmozgalom a térségben}

A Balaton Kiemelt Üdülőkörzet települései közül 110 népessége 2000-hez képest csökkent, ez a települések 61,5\%-a. 35 település lélekszáma nőtt, míg a települések 19\%-a, összesen 34 település lélekszáma a 2011 előtti és utáni időszakban eltérő tendenciát mutat. Ebből a 34 településből a következő 10 település népessége stagnált vagy alig változott, kezdetben kismértékben növekedett, majd enyhén csökkent: Zamárdi, Taliándörögd, Ságvár, Lesenceistvánd, Barnag, Balatonszabadi, Balatonlelle, Balatonföldvár, Aszófó és Alsópáhok. Ide sorolhatnánk Kékkút települést is, amelynek a népessége 2010 után jelentősen visszaesett, de ez az alacsony lélekszám miatt nem értékelhető. 2001-ben 63 főről indult, 2006-ig emelkedett (103 lakosa volt), majd 2016-ra a 2002-es 70 fónyi létszámra csökkent vissza. (Ez az ideiglenes népességszám növekedés a 2006-os választások eredményeinek befolyásolása érdekében történő, néhány címre való bejelentkezésnek tudható be (https://24.hu/belfold/2006/10/11/kekkut_ujra_valaszt/).

A Balaton térség lakónépessége 15 év alatt 9 ezer fővel csökkent, a csökkenés mértéke az elmúlt években enyhülni látszik (1. táblázat).

\section{1. táblázat - Table 1}

A Balaton Kiemelt Üdülókörzet lakónépessége településcsoportok szerint Population of the settlements' group

\begin{tabular}{cccc}
\hline $\begin{array}{l}\text { Lakónépesség száma } \\
\text { (január 1.) }\end{array}$ & $\mathbf{2 0 0 1}$ & $\mathbf{2 0 1 1}$ & $\mathbf{2 0 1 6}$ \\
\hline parti város & 102653 & 101807 & 101412 \\
nem parti város & 40535 & 37063 & 36003 \\
Város összesen & 143188 & 138870 & 137415 \\
parti község & 42941 & 44789 & 45922 \\
nem parti község & 81778 & 76100 & 75546 \\
Község összesen & 124719 & 120889 & 121468 \\
BKÜ együtt & $\mathbf{2 6 7 9 0 7}$ & $\mathbf{2 5 9 7 5 9}$ & $\mathbf{2 5 8 8 8 3}$ \\
\hline
\end{tabular}

Forrás: KSH-adatok alapján saját számítás

Source: own calculation based on HCSO 
Részcsoportonként vizsgálva a népességváltozást, azt tapasztaljuk, hogy a városok lakosságszáma csökkenő tendenciát mutat: a parti városokra a stagnálás a jellemző, míg a nem parti városok lakosságszáma több mint 4 ezer fővel lett kevesebb. 2018-ra tovább csökkent a városok össznépessége közel kétezer fővel. A parti községek összlakosságszáma nőtt az elmúlt 15 évben és a növekedés tendenciája csak kismértékben csökkent, ugyanakkor a nem parti községek népességvesztesége mérséklődött 2011-2016 között, de az utóbbi két évben ismét intenzívebbé vált a csökkenés. Az elmúlt 15 év népességi és népmozgalmi adatait vizsgálva van remény arra, hogy a népességcsökkenés lassulni fog a jövőben, esetleg megállítható, bár ehhez az elvándorlás csökkenésére, a bevándorlás fokozódására, a fiatalabb népesség helyben maradására és gyermekvállalására lenne szükség.

Az elmúlt 15 évben a Balaton térség területén mind a parti, mind a háttértelepüléseken egyaránt többen haltak meg, mint ahányan születtek. A régió egészére több mint 20 ezer fős hiány keletkezett a természetes fogyás eredményeképpen. A belföldi migráció a parti településeken - a parti, partközeli városokban és a parti, partközeli községcsoportban is pozitív mérleggel zárta a 15 évet. A vándorlásból eredő népességnyereség a térség korszerkezetét az idősödés felé tolja, mivel a beköltözők átlagéletkora magasabb, mint az elvándorlók átlagéletkora (AGG Z. 2013, CsÁKVÁRINÉ és tsai 2015, BANÁSZ Zs.-BIERMANN M. 2018).

Önmagában a nemzetközi migráció a belföldi migrációval együtt sem tudja megállítani a népességfogyást, ha a beköltözők átlagéletkora 40 év fölött marad.

A nem parti településekről, ideértve a nem parti városokat is, összességében többen költöztek el, mint ahányan bevándoroltak. Így a nem parti települések népességszáma erôsen csökkent, míg a parti településeken a vándorlás enyhítette az alacsony születésszámból és magasabb halálozási számból eredő hiányt.

A háttértelepülések közel 60\%-a 500 fő alatti lélekszámú, míg a parti községek 23\%-a. A nem parti községek kevesebb, mint 20\%-a 1000 fő feletti, míg a parti községeknek 51\%-a meghaladja ezt az értéket (2. táblázat).

Az elnéptelenedés folyamata a tartós természetes fogyás és negatív vándorlásból eredően elsősorban a parttól távolabb eső törpefalvakat veszélyezteti. 100 fö alatti települést csak a parttól távolabb találunk, összesen nyolcat, közülük kettő népességszáma nem csökken

2. táblázat-Table 2

A Balaton Kiemelt Üdülőkörzet településeinek méret szerinti megoszlása Distribution of settlements by size in the Balaton Region

\begin{tabular}{|c|c|c|c|c|}
\hline $\begin{array}{l}\text { Település- } \\
\text { méretkategória }\end{array}$ & város & $\begin{array}{c}\text { parti vagy } \\
\text { partközeli } \\
\text { község }\end{array}$ & $\begin{array}{l}\text { nem parti } \\
\text { község }\end{array}$ & Összesen \\
\hline 100 fós és kisebb & 0 & 0 & $8 \quad(6,5 \%)$ & $(4,4 \%)$ \\
\hline 101-500 fó & 0 & $9(23,1 \%)$ & $65(52,8 \%)$ & $74(41,1 \%)$ \\
\hline 501-1000 fö & 0 & $10(25,6 \%)$ & $26(21,1 \%)$ & $36(20,0 \%)$ \\
\hline 1001-3000 fö & $5(27,8 \%)$ & $19(48,7 \%)$ & $24(19,5 \%)$ & $48(26,7 \%)$ \\
\hline 3001-5000 fó & $5(27,8 \%)$ & $1 \quad(2,6 \%)$ & 0 & $6 \quad(3,3 \%)$ \\
\hline 5001-10000 fó & $3(16,7 \%)$ & 0 & 0 & $3 \quad(1,7 \%)$ \\
\hline 10000 fó felett & $5(27,8 \%)$ & 0 & 0 & $5 \quad(2,8 \%)$ \\
\hline Összesen & $18(100,0 \%)$ & $39(100,0 \%)$ & $123(100,0 \%)$ & $180(100,0 \%)$ \\
\hline
\end{tabular}

Forrás: KSH 2015 adatok alapján saját szerkesztés

Source: own calculation based on HCSO, 2015 
(Kékkút, Salföld). A hat fogyó törpefalu közül (Zalaszentmárton, Vindornyalak, Tagyon, Főnyed, Óbudavár, Vöröstó) Zalaszentmárton népessége csökkent a legjelentősebb mértékben, 38\%-kal csökkent 2001-hez képest. Vöröstó és Főnyed népessége 25\%-kal, Óbudavár és Vindornyalak 12-13\%-kal, Tagyon mindössze 4,4\%-kal lett kevesebb. Ha ez a tendencia folytatódik, Zalaszentmárton 35 év múlva válik lakatlanná. Fơnyed 2001-2010 közötti 30\%-os népességvesztesége után kismértékű emelkedés következett, majd folytatódott a népességcsökkenés a korábbi tendencia szerint, így ugyancsak ki van téve az elnéptelenedés folyamatának.

Kevésbé vannak kitéve a kiürülés veszélyének a partközeli települések, bár előfordulhat, hogy üdülőfaluvá válik egy-egy kisebb község. Összesen 9 partközeli falu lakosságszáma volt 100 és 500 fö között 2015-ben. Közülük Aszófó, Lovas és Paloznak lakosságszáma nőtt az elmúlt 15 évben. Az öt népességvesztő település közül Ábrahámhegy 2003 óta, Balatonőszöd pedig 2015-re lett 500 fő alatti település a népességcsökkenés következtében. A legnagyobb arányú veszteséget Ábrahámhegy szenvedte el, több mint 15\%-kal esett vissza a lakosságszám.

A 100-500 fö közötti háttértelepülések közül 14 község népességvesztesége 20-30\% közötti, 13 községnek 15-20\% közötti, 8 községnek 10-15\% közötti, 10 községnek 5-10\% közötti, míg 7 községnek 5\% alatti volt a népességvesztesége. Szólád és Balatonújlak csak 2012-2013-ban csúszott le az 500 fó alatti településcsoportba. Van 5 község, ahol 30\%-ot is meghaladja a népességveszteség 15 év alatt. Amennyiben ezek a tendenciák folytatódnak, 40 éven belül mind az öt falu elnéptelenedik.

Mindszentkálla és Szentbékkálla esetében 2018 január 1-jei lakosságszám alapján van remény, előbbin 228 főról 249 főre, 21 fővel nőtt a lakosságszám, utóbbin már negyedik éve tapasztalható a népességszám lassú emelkedése (174-ről 188 fớre), de Monoszló, Bókaháza és Hollád esetében további csökkenést tapasztaltunk (1. ábra).

A 123 nem parti község közül összesen 21-ben nőtt a népességszám 2001-hez képest.

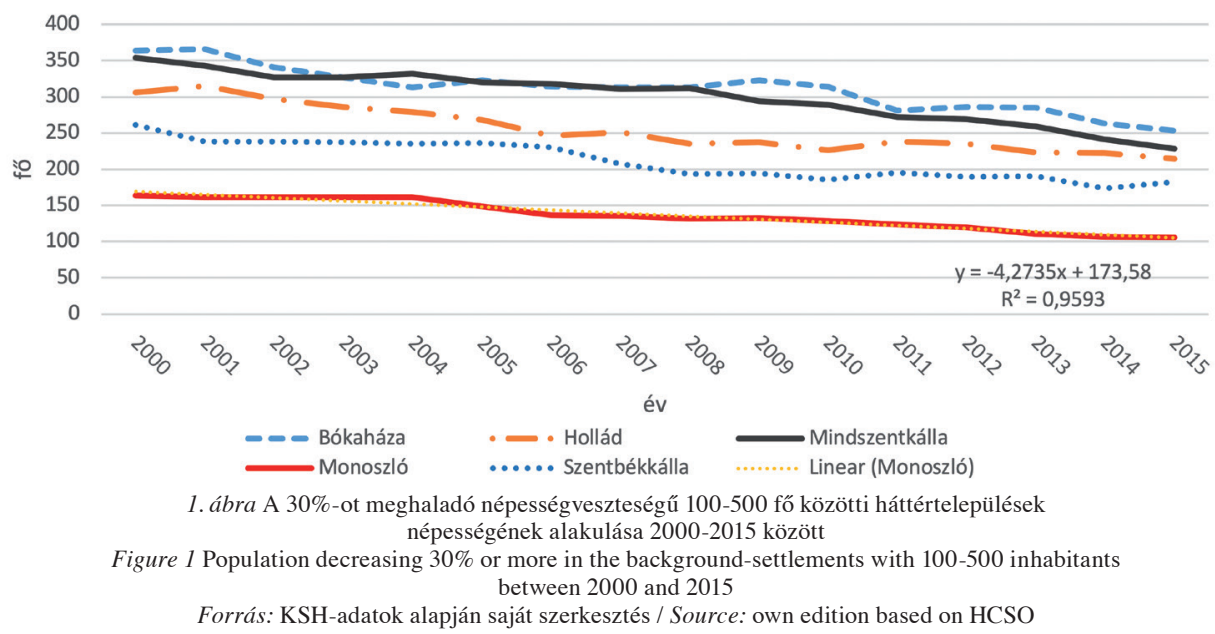

\section{Népességdinamikai csoportok}

Általában az elöregedő-kihaló népességnek és a fiatalok elvándorlásának eredménye a falvak elnéptelenedése. Az elvándorlás oka pedig a megfelelő infrastruktúra - iskola, óvoda, járható úthálózat - és a munkalehetôségek hiánya vagy a munkabérek alacsony 
színvonala. Magyarországon 237 olyan népességvesztő település van, amelyek 1980 óta 3 évtizeden keresztül, dekádonként, népszámlálástól népszámlálásig a népesség mind a vándorlási különbözet, mind pedig a természetes fogyás eredményeképpen csökken. Ezek 78,5\%-a 500 fő alatti település.

Összefoglalva a Balaton Kiemelt Üdülőkörzet településeire jellemző demográfiai folyamatokat, hat csoportba soroltuk a településeket népességdinamikai szempontok alapján. A két fő csoport a növekvő népességgel rendelkező, illetve a népességvesztő települések csoportja. A népességnövekvő csoportba 45 település tartozik (3. táblázat). Három alcsoportja közül az elsőbe azok a települések tartoznak, amelyeknek pozitív vándorlási egyenlege van és természetes szaporodás jellemzi, tehát mindkét folyamat népességnövelő hatású. Az itt található öt település közül Kisberényben a 2011-es népszámláláskor a lakosság több mint $22 \%$-a cigánynak vallotta magát. A második csoportba azok a települések tartoznak, amelyeknek a vándorlási egyenlege pozitív, de természetes fogyás jellemzi, a kettő együttes egyenlege azonban pozitív. Végül a harmadik csoportba tartozó településeken az elvándorlás meghaladta a bevándorlást, de a születések számának és a halálozások számának különbözetével együtt pozitív egyenleggel zárt. Egyetlen ilyen település van a Balaton régió területén, a nazarénusok lakta Szentantalfa.

3. táblázat - Table 3

Növekvő népességú települések 3 csoportja (2001-2016)

3 types of the settlements with population increasing (2001-2016)

Pozitív vándorlás, Kisberény (háttértelepülés, $22 \%$ cigány),

természetes szaporodás Balaton-felvidék: Litér, Cserszegtomaj, Tótvázsony, Felsőörs

$\mathrm{N}=5$

Pozitív vándorlás, természetes fogyás $\mathrm{N}=39$

Negatív vándorlás,

természetes szaporodás (nazarénusok lakta település a Balaton-felvidéken) $\mathrm{N}=1$
Alsóörs, Alsópáhok, Aszófő, Badacsonytördemic, Balatonalmádi, Balatoncsicsó, Balatonföldvár, Balatongyörök, Balatonlelle, Balatonmáriafürdő, Balatonszabadi, Balatonszőlős, Barnag, Csopak, Felsőpáhok, Gyenesdiás, Gyugy, Hegymagas, Hévíz, Káptalantóti, Kékkút, Lesenceistvánd, Lovas, Nemesbük, Paloznak, Pécsely, Rezi, Ságvár,

Salföld, Siófok, Siójut, Somogytúr, Szántód, Szőlősgyörök, Taliándörögd, Vászoly, Vonyarcvashegy, Zalakaros, Zamárdi

Szentantalfa

Forrás: saját szerkesztés

Source: own edition

A települések második nagy főcsoportja a népességvesztő csoport. Itt is három alcsoportba sorolhatók a települések népességdinamikai szempontok alapján (4. táblázat). Az első csoportba tartoznak azok a népességvesztő települések, amelyek esetében mindkét demográfiai jellemző negatívan befolyásolja a népességszámot. A második csoportba azokat a településeket soroltuk, ahová többen költöznek be, mint ahányan elköltöznek, de ez a természetes fogyást nem tudja ellensúlyozni, így a népesség csökkenő. A harmadik csoportba a természetes szaporodású, de negatív vándorlási egyenlegú települések tartoznak.

Mindössze három háttértelepülés esetében beszélhetünk csökkenő népességszám és elvándorlás mellett pozitív természetes szaporodási mutatóról. Somogysámson, Somogy- 
szentpál és Teleki a Balaton déli oldalán, nem partközeli települések. Mindhárom településen a 2011-es népszámláláskor igen magas volt a magukat cigánynak vallók aránya.

Népességvesztő települések 3 csoportja (2001-2016)

4. táblázat-Table 4

3 types of the setlements with population decreasing (2001-2016)

\begin{tabular}{|c|c|}
\hline $\begin{array}{l}\text { Negatív vándorlási } \\
\text { egyenleg, } \\
\text { természetes fogyás } \\
\mathrm{N}=79\end{array}$ & $\begin{array}{l}\text { Zalaszentmárton, Vindornyalak, Örvényes, Vigántpetend, } \\
\text { Egeraracsa, Tikos, Zalacsány, Gamás, Bókaháza, Nikla, Hács, } \\
\text { Öreglak, Zalaszabar, Mindszentkálla, Lengyeltóti, Somogy- } \\
\text { vár, Öcs, Táska, Monostorapáti, Torvaj, Ordacsehi, Köveskál, } \\
\text { Zalaszántó, Som, Balatonmagyaród, Balatonederics, } \\
\text { Kővágóörs, Csömend, Tapolca, Garabonc, Nemesvita, } \\
\text { Hidegkút, Monoszló, Bábonymegyer, Balatonvilágos, Karád, } \\
\text { Balatonőszöd, Balatonszemes, Raposka, Gétye, Zalavár, } \\
\text { Somogybabod, Balatonújlak, Küngös, Badacsonytomaj, Uzsa, } \\
\text { Szentkirályszabadja, Szentbékkálla, Andocs, Somogy- } \\
\text { meggyes, Sérsekszoólós, Balatonendréd, Esztergályhorváti, } \\
\text { Nagyberény, Tab, Karmacs, Sávoly, Szólád, Vállus, } \\
\text { Balatonfókajár, Balatonudvari, Balatonszepezd, Főnyed, Zala, } \\
\text { Révfülöp, Marcali, Csajág, Szentjakabfa, Balatonboglár, } \\
\text { Hollád, Fonyód, Vindornyafok, Szegerdő, Kereki, Ádánd, } \\
\text { Zalaújlak, Veszprémfajsz, Kisapáti, Ábrahámhegy }\end{array}$ \\
\hline $\begin{array}{l}\text { Pozitív vándorlási } \\
\text { egyenleg, } \\
\text { természetes fogyás } \\
\mathrm{N}=52\end{array}$ & $\begin{array}{l}\text { Balatonakali, Balatonberény, Balatonfenyves, Balatonfüred, } \\
\text { Balatonfúzfő, Balatonhenye, Balatonkenese, Balatonkeresztúr, } \\
\text { Balatonrendes, Balatonszárszó, Balatonszentgyörgy, } \\
\text { Bálványos, Buzsák, Csapi, Dióskál, Dörgicse, Galambok, } \\
\text { Gyulakeszi, Hegyesd, Kapolcs, Kapoly, Keszthely, Kéthely, } \\
\text { Köröshegy, Kötcse, Látrány, Lesencefalu, Lesencetomaj, } \\
\text { Lulla, Mencshely, Nagycsepely, Nagyrada, Nagyvázsony, } \\
\text { Nemesgulács, Nyim, Obudavár, Pula, Pusztaszemes, } \\
\text { Sármellék, Szentgyörgyvár, Szigliget, Tagyon, Tihany, } \\
\text { Várvölgy, Vindornyaszőlős, Visz, Vöröstó, Vörs, Zalaapáti, } \\
\text { Zalakomár, Zalamerenye, Zánka }\end{array}$ \\
\hline $\begin{array}{l}\text { Negatív vándorlási } \\
\text { egyenleg, természetes } \\
\text { szaporodás } \mathrm{N}=3\end{array}$ & $\begin{array}{l}\text { Háttértelepülések, } \\
\text { dél-Balaton: Somogysámson ( } 35 \% \text { cigány), } \\
\text { Somogyszentpál (28\% cigány), Teleki (16,7\% cigány) }\end{array}$ \\
\hline
\end{tabular}

Forrás: saját szerkesztés

Source: own edition

Az 5. táblázatban a területi elhelyezkedés és a népességdinamikai csoport közötti összefüggést mutatjuk be. A települések 44\%-ának mindkét demográfiai jellemzője negatív egyenlegú. A nem parti községek 50\%-a és a parti községek kevesebb, mint 30\%-a tartozik ebbe a csoportba, míg a városoknak a 39\%-a. Az ebbe a csoportba tartozó 79 településből 61 nem partközeli község, demográfiai szempontból hátrányos, népességfogyás szempontjából kifejezetten veszélyeztetett helyzetúek.

Alapvetően a pozitív népességdinamikát a vándorlás mozgatja. 39 településen növekvő a népesség pozitív vándorlási egyenleg és a természetes fogyás mellett. A városok 39\%-a, a parti és partközeli községek 36\%-a tartozik ebbe a kategóriába, míg a háttértelepüléseknek kevesebb mint $15 \%$-a. 
A területi elhelyezkedés és a népességdinamikai típus közötti kapcsolat Relationship between location and population dynamic type

\begin{tabular}{|c|c|c|c|c|c|c|c|}
\hline Csoport & 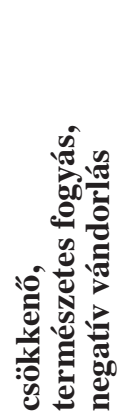 & 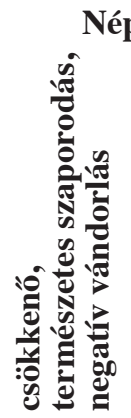 & 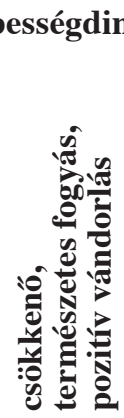 & 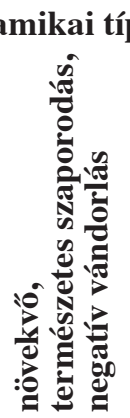 & 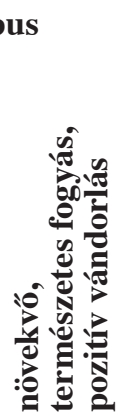 & 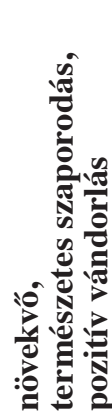 & :Öss \\
\hline város & $\begin{array}{c}7 \\
38,9 \%\end{array}$ & $\begin{array}{c}0 \\
0,0 \%\end{array}$ & $\begin{array}{c}4 \\
22,2 \%\end{array}$ & $\begin{array}{c}0 \\
0,0 \%\end{array}$ & $\begin{array}{c}7 \\
38,9 \%\end{array}$ & $\begin{array}{c}0 \\
0,0 \%\end{array}$ & $\begin{array}{c}18 \\
100,0 \%\end{array}$ \\
\hline $\begin{array}{l}\text { parti vagy part- } \\
\text { közeli község }\end{array}$ & $\begin{array}{c}11 \\
28,9 \%\end{array}$ & $\begin{array}{c}0 \\
0,0 \%\end{array}$ & $\begin{array}{c}11 \\
28,9 \%\end{array}$ & $\begin{array}{c}0 \\
0,0 \%\end{array}$ & $\begin{array}{c}14 \\
36,8 \%\end{array}$ & $\begin{array}{c}2 \\
5,3 \%\end{array}$ & $\begin{array}{c}38 \\
100,0 \%\end{array}$ \\
\hline nem parti község & $\begin{array}{c}61 \\
49,6 \%\end{array}$ & $\begin{array}{c}3 \\
2,4 \%\end{array}$ & $\begin{array}{c}37 \\
30,1 \%\end{array}$ & $\begin{array}{c}1 \\
0,8 \%\end{array}$ & $\begin{array}{c}18 \\
14,6 \%\end{array}$ & $\begin{array}{c}3 \\
2,4 \%\end{array}$ & $\begin{array}{c}123 \\
100,0 \%\end{array}$ \\
\hline BKÜ Együtt & $\begin{array}{c}79 \\
44,1 \%\end{array}$ & $\begin{array}{c}3 \\
1,7 \%\end{array}$ & $\begin{array}{c}52 \\
29,1 \%\end{array}$ & $\begin{array}{c}1 \\
0,6 \%\end{array}$ & $\begin{array}{c}39 \\
21,8 \%\end{array}$ & $\begin{array}{c}5 \\
2,8 \%\end{array}$ & $\begin{array}{c}179 \\
100,0 \%\end{array}$ \\
\hline
\end{tabular}

Forrás: saját szerkesztés

Source: own calculation and edition

\section{A népesség-elóreszámítás hipotézisei}

\section{Termékenységi arány}

A termékenységi arány a Balaton körzetében 2016-ban 1,47 volt, amely feltételezésünk szerint emelkedik a következó években, majd 2021-re eléri az 1,6-es értéket és ezt stabilan megtartja. Ez kismértékben elmarad a jelenlegi országos hipotetikus értéktől, de a múltbeli értékek is alacsonyabbak voltak az országos értéknél. Az agglomeratív eljárásnál egyféle termékenységgel számoltunk a Régió egészére, míg a második módszernél a különböző karakterisztikájú településcsoportokra eltérő termékenységi arányt alkalmaztunk.

\section{Születéskor várható élettartam területi különbségei}

A születéskor várható élettartam Magyarországon 2016-ban a nők esetében 79,2, a férfiak esetében 72,4 volt. Országon belül a megyékre, illetve a járásokra kisebb-nagyobb eltéréseket mutat. A várhatóan megélt évek száma Borsod-Abaúj-Zemplén megyében a legalacsonyabb 2016-ban, a férfiak esetében 70,2 évvel, a nők esetében 77,5 évvel, a legmagasabb pedig Győr-Moson-Sopron megyében a férfiak 73,5 és a nők 80,2 évével.

A születéskor várható élettartamot megyesorosan a KSH publikálja, járási szintre azonban csak ötéves átlagban számolható ki a kis területi egység miatt. Így a születéskor várható élettartam járási szinten, az elmúlt öt év átlagára lett meghatározva. A Balaton 
Kiemelt Üdülőkörzet települései 11 járáshoz tartoznak, ebből az ajkai járáshoz csak egy község, Öcs. A születéskor várható élettartam értékek alapján a 11 érintett járást 4 csoportba soroltuk. A precízebb számításhoz figyelembe vettük a területi különbségeket az alábbiak szerint: a születéskor várható élettartam a 4 csoport esetében a 2016-ban a Balaton Kiemelt Üdülőkörzetre vonatkozó érték és az országos érték eltérése alapján a 2062-re előrejelzett országos értékekhez viszonyítva került megállapításra. Az agglomeratív eljárásnál a születéskor várható élettartam esetében nem vettünk figyelembe területi eltéréseket, a második módszer esetében az eltérő karakterisztikájú településcsoportokra eltérő hipotéziseket állítottunk fel a születéskor várható élettartamra.

Az egyes települések attól függóen, hogy melyik csoportba tartoznak, más-más születéskor várható élettartam értékkel kerülhetnek a népesség-előreszámítási eljárásba. A járáson belüli települések születéskor várható élettartama az adott járás értékével azonosnak tekintendő.

Figyelembe véve a korábbi népesség-előreszámítást és az ott alkalmazott születéskor várható élettartam értékeket, valamint az attól való eltérést, az egyes csoportokra a következő születéskor várható élettartam értékeket a 6. táblázatban található módon határoztuk meg. A férfiak és nők születéskor várható élettartam értéke a kezdeti időszakban 7 évnyi különbséggel indul, a vizsgált időszak végére - 45 év múlva - ez az eltérés 2 évre mérséklődik. Ezt a hipotézist az érvényben lévő legutóbbi népesség-előreszámítás tartalmazza (ОвÁDOVICS 2018).

6. táblázat - Table 6

A születéskor várható élettartamának ötéves átlaga és csoportosítása az érintett járásokban

Grouping of the life expectancy at birth of the small regions

\begin{tabular}{|c|c|c|c|c|c|}
\hline \multirow{3}{*}{ Csoport } & \multirow{3}{*}{ Járások } & \multicolumn{4}{|c|}{$\begin{array}{l}\text { Születéskor várható élettartam } \\
\text { ötéves átlaga és várható értéke 2061-re }\end{array}$} \\
\hline & & \multicolumn{2}{|c|}{ férfi } & \multicolumn{2}{|c|}{ no" } \\
\hline & & 2016 & 2061 & 2016 & 2061 \\
\hline 1. csoport - alacsony & $\begin{array}{l}\text { Tabi járás } \\
\text { Marcali járás }\end{array}$ & 70 & 82 & 77 & 84 \\
\hline $\begin{array}{l}\text { 2. csoport } \\
\text { - mérsékelten alacsony }\end{array}$ & $\begin{array}{l}\text { Fonyódi járás } \\
\text { Nagykanizsai járás } \\
\text { Ajkai járás }\end{array}$ & 72 & 84 & 79 & 86 \\
\hline $\begin{array}{l}\text { 3. csoport } \\
\text { - mérsékelten magas }\end{array}$ & $\begin{array}{l}\text { Keszthelyi járás } \\
\text { Veszprémi járás } \\
\text { Balatonalmádi járás } \\
\text { Tapolcai járás } \\
\text { Siófoki járás }\end{array}$ & 73 & 85 & 80 & 87 \\
\hline 4. csoport - magas & Balatonfüredi járás & 75 & 87 & 81 & 90 \\
\hline
\end{tabular}

Forrás: saját számítás

Source: own calculation

\section{Belföldi vándorlás és nemzetközi migráció}

A legbizonytalanabb tényezője az előreszámításnak a migráció előrejelzése, amelyre különböző társadalmi-gazdasági és politikai tényezők hatnak. A vándorlás az a tényezője 
a demográfiának, amely viszonylag rövid időn belül válaszol az említett hatásokra. Ezért nagyon nehéz megbízható hipotézist felállítani erre a paraméterre.

Alaphipotézisként feltételezhetnénk, hogy a migrációs folyamatok a korábbi évek tendenciáját követik a jövőben, de ez nem lenne reális, hiszen ahogyan azt a korábbi tanulmány felülvizsgálata során tapasztaltuk, a migrációs folyamatokra nem jellemző, hogy a meredeken emelkedő, vagy éppen csökkenő tendenciák tartósan érvényben maradnának. Ha így lenne, néhány kistelepülés 2062-re gyakorlatilag teljesen kiürülne, mint ahogyan erre több példát is találni az országban (elsősorban az aprófalvairól híres Baranyában és Borsod-Abaúj-Zemplén megyében, Baranyában közel húsz település szúnt meg, BAZ megyében Nagyecsér, Derenk, Gyertyánvölgy, Somogyban Márcadópuszta és még sorolhatnánk).

A jövőre vonatkozó hipotézisek közül ezt a legnehezebb 50 évre előre védhetô módon megjósolni. Ezért a migrációra nézve egy olyan hipotézist állítottunk fel, amely a településeket csoportokra osztja: egy migráció nélküli csoportra, - ahol a belföldi vándorlási egyenleget nullának tekintjük, - és az elmúlt öt év átlagos vándorlási egyenlegét fenntartó csoportra, ahol az elmúlt 5 év be-, illetve elvándorlóinak átlagos kormegoszlását vesszük alapul.

A nemzetközi vándorlási adatok nyilvántartási pontatlansága miatt a településekre nemzetközi migrációt nem veszünk figyelembe. Az adatok ismeretében egyes városok, illetve nagyközségek tekintetében alulbecslés történik a jövőbeni népességszámokra.

A következő csoportosítás a belföldi migráció alapján készült:

- „A” települések: a vándorlási egyenleg nulla: A községek összessége ide tartozik és a városok közül Balatonfüzfő, Zamárdi, Hévíz, Keszthely

- „B” települések: a vándorlási egyenleg az elmúlt öt év átlagát követi.

Az életkor szerinti vándorlási arányszámok előrebecslésénél a 2012-2016 közötti vándorlási korprofilokat használtuk. Öt év után az el- és bevándorlás kiegyenlítődik és a továbbiakban nem számolunk migrációs hatással.

A migrációs egyenleget a csoportok egészére végzett (második módszer) előreszámítás esetében nullának tekintettük, ami annyit jelent, hogy a városokba, a parti településekbe illetve a nem parti községekbe összességében ugyanannyian költöznek be, mint ahányan onnan elvándorolnak.

\section{Hipotézisek összefoglalása}

Az agglomeratív előreszámításhoz alkalmazott paramétereink a következők voltak:

- a fertilitás a jelenlegi 1,47-es értékról fokozatosan 1,6-ra emelkedik, majd megmarad ezen a szinten az időszak végéig;

- születéskor várható élettartam 2061-re a férfiak esetében 84,4 év, a nők esetében 88,4 év lesz;

- belföldi migrációval csak néhány város esetébe számolunk úgy, hogy a következő öt évre megtartja az elmúlt öt év átlagos migrációs egyenlegét, majd öt év múlva kiegyenlítődik az oda- és elvándorlás, így a továbbiakban nem számolunk migrációs hatással;

- nemzetközi migrációs hatást nem építettünk be a modellbe.

A második módszer esetében figyelembe vettük a járásonkénti különbözőségeket a születéskor várható élettartam és a termékenység esetében is. Az adott járás országostól való eltérés mértékének megfelelően határoztuk meg a jövőbeli várható élettartam értékeket illetve a termékenységi arányszámot, az adott járásba tartozó települések együttesére, így a parti községekre, a nem parti községekre és a városok együttesére vonatkozóan három-három forgatókönyv mentén számítottuk előre a népességet. Ebben a verzióban migrációs hatással nem számoltunk. 


\section{A Balaton Kiemelt Üdülőkörzet népesség-előreszámításának eredményei}

A kétféle módszerrel készült előreszámítás végeredménye a településcsoportok egészére nem mutat lényeges eltérést. Az itt bemutatásra kerülő népesség-előreszámítás (7. táblázat) alapvetően egy pesszimista, migráció nélküli változat. A jelentősebb migrációval rendelkező városok esetében számoltunk csak migrációs folyamatokkal, azok esetében is csak az elkövetkezendő öt évben. Ezek ismeretében mondhatjuk azt is, hogy ennél csak kedvezőbben alakulhatnak a demográfiai folyamatok a térségben. Fel kell hívni ugyanakkor a figyelmet arra, hogy mivel a vándorlás a népesség öregedését erósíti, egy idő után a szülőképes korú női népesség csökkenése, a születések számának visszaesése a népesség utánpótlását nem teszi lehetővé, felgyorsul a népességvesztés.

A népesség-előreszámítás során alkalmazott hipotéziseink néhány településre korlátozták a belföldi migráció hatását a korábbi tendenciák öt évre szóló kiterjesztésével. A feltételezés szerint öt év múlva az elvándorlás és bevándorlás kiegyenlítődik, a vándorlók kormegoszlása közel azonos lesz, így migrációs hatásról nem beszélhetünk.

7. táblázat - Table 7

A kétféle népesség előreszámítás eredménye (fö)

Results of the Population Projections (inhabitants)

\begin{tabular}{lrrrrr}
\hline Agglomeratív eljárás & $\mathbf{2 0 1 7}$ & $\mathbf{2 0 2 7}$ & $\mathbf{2 0 3 7}$ & $\mathbf{2 0 4 7}$ & $\mathbf{2 0 5 7}$ \\
\hline Városok együtt & 136917 & 126690 & 116649 & 107278 & 99271 \\
Parti községek & 46302 & 42466 & 38662 & 35185 & 32293 \\
Nem parti községek & 75163 & 71585 & 67691 & 63429 & 59447 \\
Balaton Kiemelt Üdülókörzet & $\mathbf{2 5 8 3 8 2}$ & $\mathbf{2 4 0 7 4 1}$ & $\mathbf{2 2 3 0 0 2}$ & $\mathbf{2 0 5 8 9 1}$ & $\mathbf{1 9 1 0 1 1}$ \\
\hline \hline Csoportos eljárás & $\mathbf{2 0 1 7}$ & $\mathbf{2 0 2 7}$ & $\mathbf{2 0 3 7}$ & $\mathbf{2 0 4 7}$ & $\mathbf{2 0 5 7}$ \\
\hline Városok együtt & 136584 & 127403 & 117020 & 107428 & 98896 \\
Parti községek & 45921 & 42022 & 37970 & 34420 & 31368 \\
Nem parti községek & 75215 & 71365 & 67015 & 62322 & 57854 \\
Balaton Kiemelt Üdülókörzet & $\mathbf{2 5 7 7 2 0}$ & $\mathbf{2 4 0 7 9 0}$ & $\mathbf{2 2 2 0 0 6}$ & $\mathbf{2 0 4 1 7 0}$ & $\mathbf{1 8 8 1 1 7}$ \\
\hline
\end{tabular}

Forrás: saját számítás

Source: own calculation

A kétféle népesség előreszámítási eredmény között nincs lényeges eltérés. Az idő előrehaladtával nő ugyan a különbség, de az utolsó időpontban is csak 1,5\% (népességszámra vetítve) az eltérés a két előreszámítás végeredménye között. Az agglomeratív eljárásnál a városok és a parti községek lakosságszáma enyhén magasabb, mint a másik módszer esetén. Ez egyrészt annak tulajdoníthat, hogy az első módszernél a modellbe beépítésre kerül a belső migráció a városok egy részénél. Az eltérést okozhatja az is, hogy a második módszernél differenciáltuk a termékenységet és a születéskor várható élettartamot a járásoknak megfelelően.

A Balaton Régió összességében a 2016-os lakosságszámának 26\%-át veszíti el 2062-re (8.táblázat). A parti községek népesség-vesztesége eléri a 30\%-ot az előreszámítás végére, míg a nem parti községek csökkenése 21-22\% körül várható. A népességcsökkenést erősíti 
az a speciális helyzet, hogy a kedvező környezet miatt az üdülőtulajdonosok egy része nyugdíjas kort elérve leköltözik a Balatonhoz, ezáltal az idős korcsoport arányát növelve (AGG Z. 2013). A vándorlási egyenleg ugyan pozitív lehet, de a természetes szaporodás ellen hat a folyamat. Ez a tendencia elsősorban a parti településeket érinti, azon belül is a városok a vonzóbbak a jobb infrastruktúra és egészségügyi ellátás miatt.

A déli oldalon a háttértelepülések esetében a korábban említett etnikai összetétel a természetes szaporodás mutatónak kedvez, még ha nem is tudja kompenzálni az elvándorlásból eredő hiányt, de mérsékelni képes.

Népességváltozás alakulása 2016-2062 között (\%)

8. táblázat - Table 8

Population change between 2016 and $2062(\%)$

\begin{tabular}{lrllll}
\hline $\mathbf{2 0 1 6 = 1 0 0 \%}$ & $\mathbf{2 0 1 7}$ & $\mathbf{2 0 2 7}$ & $\mathbf{2 0 3 7}$ & $\mathbf{2 0 4 7}$ & $\mathbf{2 0 5 7}$ \\
\hline Városok együtt & $100,2 \%$ & $92,8 \%$ & $85,4 \%$ & $78,5 \%$ & $72,7 \%$ \\
Parti községek & $100,8 \%$ & $92,5 \%$ & $84,2 \%$ & $76,6 \%$ & $70,3 \%$ \\
Nem parti községek & $99,5 \%$ & $94,7 \%$ & $89,6 \%$ & $83,9 \%$ & $78,7 \%$ \\
Balaton Kiemelt Üddülókörzet & $\mathbf{1 0 0 , 1 \%}$ & $\mathbf{9 3 , 3 \%}$ & $\mathbf{8 6 , 4 \%}$ & $\mathbf{7 9 , 8 \%}$ & $\mathbf{7 4 , 0 \%}$ \\
\hline
\end{tabular}

Forrás: saját számítás

Source: own calculation

Nézzük meg mi várható az öt elnéptelenedéssel legjobban veszélyeztetett településsel, marad-e még lakosuk 40 év múlva?

Mind az öt település népessége tovább csökken (2.ábra), de a csökkenés mérsékeltebb lesz a jövőben. Három település lakosságszáma a 150-hez konvergál, Hollád változatlan ütemben veszít a népességből, Monoszlón pedig dekádonként 10 fővel lesznek kevesebben, így 2062-re már csak 60 fő körüli létszám várható.

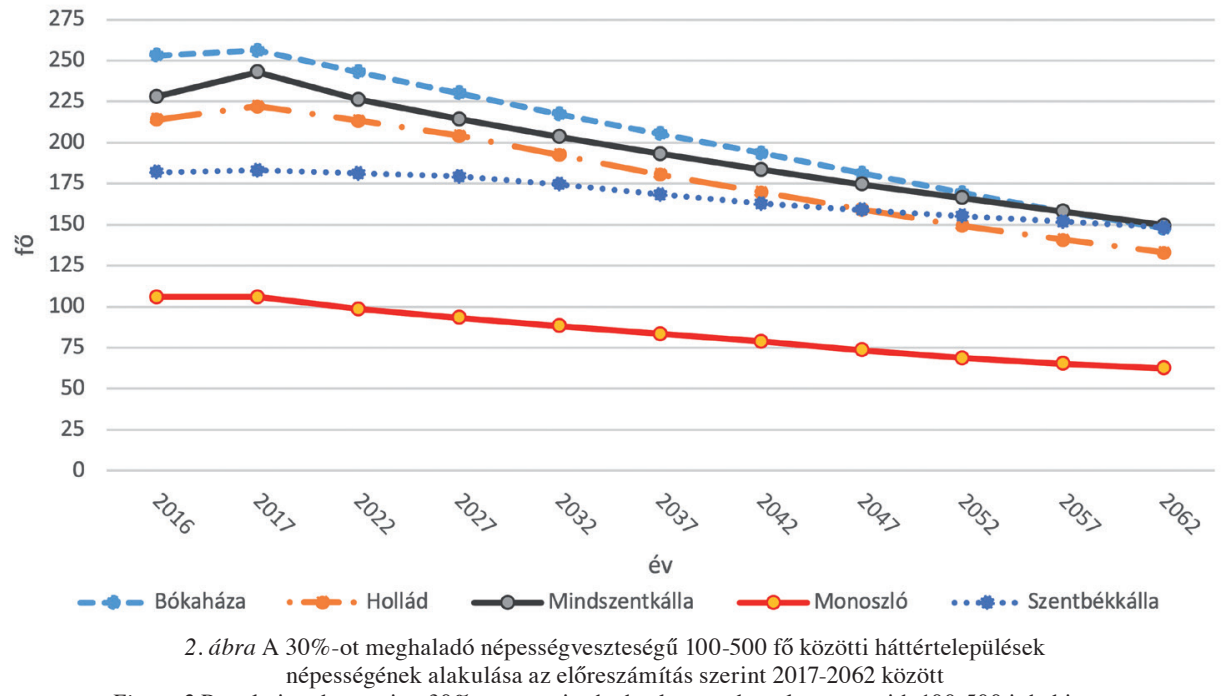

Figure 2 Population decreasing $30 \%$ or more in the background-settlements with 100-500 inhabitants based on population projection between 2017 and 2062

Forrás: KSH-adatok alapján saját szerkesztés / Source: own edition based on HCSO 


\section{A Balaton Kiemelt Üdülókörzet elóreszámított népessége föbb korcsoportok szerint}

Sok szó esett már a tanulmányban az elöregedő korszerkezetről, most nézzük meg az adatok oldaláról is (9. táblázat). A háttértelepülések korszerkezete kedvezőbb, magasabb a gyermekkorúak aránya és ez az előny megmaradni látszik a következő 40 évben is.

9. táblázat - Table 9

A népesség megoszlása korcsoportok szerint településtípusonként

Population distribution in age categories by settlements types

\begin{tabular}{crrrrrr}
\hline \multirow{2}{*}{ Életkor } & \multicolumn{2}{c}{ Városok } & \multicolumn{2}{c}{ Parti községek } & \multicolumn{2}{c}{ Háttértelepülések } \\
& $\mathbf{2 0 1 7}$ & $\mathbf{2 0 6 2}$ & $\mathbf{2 0 1 7}$ & $\mathbf{2 0 6 2}$ & $\mathbf{2 0 1 7}$ & $\mathbf{2 0 6 2}$ \\
\hline $0-14$ & 16945 & 11872 & 5508 & 3830 & 10344 & 7253 \\
$15-29$ & 20017 & 13322 & 6554 & 4247 & 13011 & 8029 \\
$30-49$ & 38331 & 20457 & 12649 & 6522 & 21006 & 12450 \\
$50-64$ & 30103 & 16506 & 10579 & 5348 & 16595 & 10219 \\
$65-79$ & 24359 & 17472 & 8711 & 5788 & 11074 & 11168 \\
$80+$ & 7162 & 16140 & 2301 & 5307 & 3133 & 8553 \\
Együtt & $\mathbf{1 3 6 9 1 7}$ & $\mathbf{9 5 7 6 8}$ & $\mathbf{4 6 3 0 2}$ & $\mathbf{3 1 0 4 2}$ & $\mathbf{7 5 1 6 3}$ & $\mathbf{5 7 6 7 2}$ \\
\hline \multirow{2}{*}{ Életkor } & $\mathbf{2 0 1 7}$ & $\mathbf{2 0 6 2}$ & $\mathbf{2 0 1 7}$ & $\mathbf{2 0 6 2}$ & $\mathbf{2 0 1 7}$ & $\mathbf{2 0 6 2}$ \\
\hline $0-14$ & $12,4 \%$ & $12,4 \%$ & $11,9 \%$ & $12,3 \%$ & $13,8 \%$ & $12,6 \%$ \\
$15-29$ & $14,6 \%$ & $13,9 \%$ & $14,2 \%$ & $13,7 \%$ & $17,3 \%$ & $13,9 \%$ \\
$30-49$ & $28,0 \%$ & $21,4 \%$ & $27,3 \%$ & $21,0 \%$ & $27,9 \%$ & $21,6 \%$ \\
$50-64$ & $22,0 \%$ & $17,2 \%$ & $22,8 \%$ & $17,2 \%$ & $22,1 \%$ & $17,7 \%$ \\
$65-79$ & $17,8 \%$ & $18,2 \%$ & $18,8 \%$ & $18,6 \%$ & $14,7 \%$ & $19,4 \%$ \\
$80+$ & $5,2 \%$ & $16,9 \%$ & $5,0 \%$ & $17,1 \%$ & $4,2 \%$ & $14,8 \%$ \\
Együtt & $\mathbf{1 0 0 , 0 \%}$ & $\mathbf{1 0 0 , 0 \%}$ & $\mathbf{1 0 0 , 0 \%}$ & $\mathbf{1 0 0 , 0 \%}$ & $\mathbf{1 0 0 , 0 \%}$ & $\mathbf{1 0 0 , 0 \%}$ \\
\hline
\end{tabular}

Forrás: saját számítás

Source: own calculation

A 65 év feletti népesség aránya 43 év múlva minden településcsoportban meghaladja a 35\%-ot (9. táblázat). Az országos érték 30\% körül várható. A 80 év feletti korcsoport jelenti a szociális támogatásra leginkább rászoruló népesség-csoportot. Az idősgondozó intézetekben élők száma a 80 év felettiek között meredek emelkedést mutat. A szociális háló, az idősgondozó rendszer kiépítése és az idősotthonok számának és minőségének javítása éppen e korosztály számának és arányának növekedése miatt lényeges. Ezért az idősödő társadalom jellemzésére a nyugdíjas korú csoporton belül a 80 év felettiekre is külön hangsúlyt fektetünk. A döntéshozók figyelmét nem kerülheti el az a ,jövendölés”, mely szerint a 80 év felettiek aránya mindegyik településcsoportban több, mint háromszorosára emelkedik. 2017-ben az országos arány 4,2\% volt, 2062-re várhatóan $11 \%$ körül alakul. A Balaton Régió városaiban és parti településcsoportjában $17 \%$ körül lesz, a háttértelepüléseken valamivel alacsonyabb, kicsivel 15\% alatt lesz az arány, de ez is 4\%-ponttal magasabb az országos értéknél. 
Az öregedési index (10. táblázat) az egyik legjellemzőbb mutatója a korszerkezet változásának, az elöregedés folyamatának. Az időskorú népességnek a gyermekkorú népességhez viszonyított arányát fejezi ki. 2017-ben még elég jelentős az eltérés az egyes településcsoportok öregedési indexében, a partközeli községekben már a kiinduláskor az idősek száma közel kétszerese a gyermekkorúak számának, míg a nem parti községek esetében ez a szorzó csak 1,3. A vizsgált időszak végére a különbségek mérséklődnek, a legalacsonyabb és legmagasabb indexérték között mindössze 0,28 (28\%pont) a különbség, a nem parti községek indexe 2,7, a parti községek indexe 2,95. Magyarország öregedési indexe 124\% volt 2017-ben már ez az érték is sokkal alacsonyabb a Balaton Régió értékénél. 2062-re 221-re emelkedik, azaz 2,2-szer annyi idős lesz, mint amennyi gyermekkorú. Ez az arány a Régióban 2,68-2,95 között várható!

Öregedési index

10. táblázat - Table 10

Ageing index

\begin{tabular}{lll}
\hline & $\mathbf{2 0 1 7}$ & $\mathbf{2 0 6 2}$ \\
\hline városok & 179,9 & 295,1 \\
parti községek & 194,3 & 286,7 \\
háttértelepülések & 135,2 & 267,9 \\
országos érték & 124,1 & 221,1 \\
\hline
\end{tabular}

Forrás: saját számítás

Source: own calculation

Az időskori függóségi ráta azt fejezi ki, hogy egy nyugdíjas korú állampolgárt hány munkaképes korú ember tart el. Ez a mutató közel duplájára emelkedik a vizsgált időszakban (11. táblázat). Amíg 2017-ben a városokban 3:1 volt az arány, addig 2062-re ez a mutató 3:2-re módosul, ami azt jelenti, hogy 3 aktív korú tart el két nyugdíjast. A legkedvezőbb a mutató alakulása a háttértelepüléseken, ahol a ráta $57,8 \%$, de ez csak akkor tekinthető kedvező helyzetnek, ha az aktívkorú népesség dolgozik is. Országosan ez a mutató 27,1\%ról 52,7\%-ra nő. E tekintetben is a kifejezetten elöregedő kategóriába tartozik a térség.

11. táblázat - Table 11

Idősödés indikátorok várható értéke 2017-ben és 2062-ben

Ageing indicators in 2017 and in 2062

\begin{tabular}{llllllc}
\hline \multirow{2}{*}{ Mutatók } & \multicolumn{2}{c}{ városok } & \multicolumn{2}{c}{ parti települések } & \multicolumn{2}{c}{ háttér-települések } \\
& $\mathbf{2 0 1 7}$ & $\mathbf{2 0 6 2}$ & $\mathbf{2 0 1 7}$ & $\mathbf{2 0 6 2}$ & $\mathbf{2 0 1 7}$ & $\mathbf{2 0 6 2}$ \\
\hline Medián életkor & 46,1 & 53,2 & 47,57 & 52,7 & 43,8 & 52,0 \\
Időskori függóségi ráta & $34,0 \%$ & $66,7 \%$ & $36,0 \%$ & $64,8 \%$ & $27,6 \%$ & $57,8 \%$ \\
\hline
\end{tabular}

Forrás: saját számítás

Source: own calculation

A medián életkor a korösszetétel egy mutatószámmal történő kifejezésére alkalmas mérőszám. A vizsgált népesség azon tagjának életkora, akinél idősebbek és fiatalabbak egyenlő számban fordulnak elő a sokaságban. A háttértelepülésen élők medián életkora 
a legalacsonyabb, a parti községekben élőké pedig a legmagasabb 2017-ben, 4,5 évnyi a különbség. 2062-re a különbség eltűnik, közel azonos medián életkor várható mindegyik településcsoportban. Magyarországra nézve a népesség-előreszámítás alapváltozata szerint 41,8-ról 48,9-re emelkedik a medián életkor, 3 évvel alacsonyabb, mint a Balaton Régióban várható.

\section{Összefoglalás}

Tanulmányunkban 2062-ig szóló népesség-előreszámítás eredményeit adtuk közre a Balaton Kiemelt Ü̉dülőkörzet településeire és településcsoportjaira összegezve, 10 évente 5 időpontra, valamint fóbb korcsoportokra. A településsoros, kisterületi becslés mindig nagy kockázattal és nagyfokú bizonytalansággal jár.

Összegzésképpen elmondható, hogy ez a pesszimista becslés a 2003-ban készült népesség-előreszámítással egybehangzó eredményt ad, miszerint 2042-re bevándorlás nélkül 215 ezer foóre csökken az üdülőkörzet népessége, továbbá az idősek aránya, a 65 év feletti népesség aránya eléri, sôt meghaladhatja a 30\%-ot. Erre hívta fel a figyelmet Hablicsek László is korábbi számításában, amikor arra figyelmeztetett, hogy a természetes reprodukcióval gondok vannak, a vándorlási többlet bizonytalan, a fiatalok létszámának és arányának csökkenése és az idősek súlyának növekedése a népesség elöregedéséhez vezet.

A falvak elöregedése mellett súlyos problémát jelent a parttól távolabb eső törpefalvak elnéptelenedése. Ha az elmúlt 15 év tendenciája folytatódik, negyven éven belül 5-6 település juthat Nagyecsér vagy Márcadópuszta sorsára. Érdemes elgondolkozni egy-egy település esetében, hogyan lehetne megállítani a további népességfogyást, hogyan lehetne a fiatalokat helyben tartani, milyen települési politikával lehetne a fiatalok számára vonzóvá tenni a természeti szépségében egyedülálló Balatoni Kiemelt Üdülőkörzet településeit. Végül, de nem utolsó sorban, mindenképpen fontos az elöregedő népesség számára az élhető környezet és élhető feltételek biztosítása.

\section{OBÁdovics CSILla}

KSH Népességtudományi Kutatóintézet, Budapest

obadovics@demografia.hu

\section{IRODALOM}

Alho, J.-Spencer, B. 2005: Statistical demography and forecasting. - Springer USA NY. 405 p.

AGG Z. 2013: Hipotézisek a klímaváltozáshoz való társadalmi gazdasági alkalmazkodás kérdéseiről, különös tekintettel a balatoni régióra. In: BESzTERI B. (Szerk.): A felfedező tudomány. https://kgk.sze.hu/images/ dokumentumok/VEABtanulmanyok/agg_zoltan.pdf

Csákváriné J. Zs.-Dombi G.-Farkas M.-Kabai G.-Kóbor I.-Kulics B.-Kun E.-Németh N.-Oláh M.-SEBESTYÉN I. 2014: Balatoni Integrációs és Fejlesztési Ügynökség Közhasznú Nonprofit Kft 2015: A Balaton Kiemelt Üdülőkörzet területi monitoringja - Balatonfüred.

BAnÁsz Zs.-Bierman M. 2018: A Balaton régió demográfiai különbözőségei.-Pannon Egyetem LX. Georgikon napok - október 4-5, Keszthely, Konferencia kiadvány pp. 17-25

FÖLDHÁZI E. 2012: A népesség szerkezete és jövője. In: ŐRI P.-SPÉDER Zs. (szerk.): Demográfiai portré KSH Népességtudományi Kutatóintézet, Budapest pp. 155-168.

HABLICSEK L. 2003: A Balaton régió demográfiai helyzete és népesség-előreszámítása, 1990-2041. - Aktív Társadalom Alapítvány, Budapest.

Hablicsek L. 2009: A népesség szerkezete és jövője. In: Monostori J.-S. MolnáR E.-Spéder Zs. (szerk.): Demográfiai portré 2009. Jelentés a magyar népesség helyzetéről. - KSH NKI, Budapest 
KSH 2011: A Balaton Kiemelt Üdülőkörzet társadalma és gazdasága. - KSH 2011. http://www.ksh.hu/docs/ hun/xftp/idoszaki/regiok/gyorbalatont.pdf

KulCSÁR L.-OBÁdOviCs Cs. 2016: Népességdinamika és társadalmi szerkezet. - Területi Statisztika 56. 4. pp. 245-274.

LENNERT J. 2019: A magyar vidék demográfiai jövőképe 2051-ig, különös tekintettel a klímaváltozás szerepére a belső vándormozgalom alakításában. Területi Statisztika 59. 5. pp. 498-525.

ОвÁDOvics Cs. 2017a: A 2003-ban Hablicsek László által készített Balaton Régió népesség-előreszámítás, 1990-2041 tanulmány alapváltozatának felülvizsgálata a 2011-es népszámlálás alapján. Kutatási jelentés. - KSH NKI, Balatoni Integrációs és Fejlesztési Ügynökség Nonprofit KFt.

ОвÁDOviCs Cs. 2017b: A Balaton Régió népesség-előreszámítása, 2016-2062. Kutatási jelentés. - KSH NKI, Balatoni Integrációs és Fejlesztési Ügynökség Nonprofit KFt.

OBÁDOvics Cs. 2018: A népesség szerkezete és jövője. In: MONOSTORI J.-Ő́RI, P.-SpÉDER Zs. (szerk.): Demográfiai portré. - KSH Népességtudományi Kutatóintézet, Budapest pp. 271-294.

Smith, S.K.-TAYman, J.-Swanson, D.A. 2002: State and Local Population Projections. Kluwer Academic Publishers, USA NY. 426 p. 